ISOTOPIC ANALYSIS OF JURASSIC (CALLOVIAN) MOLLUSKS FROM THE CHRISTIAN MALFORD

LAGERSTATTE (UK): IMPLICATIONS FOR OCEAN WATER TEMPERATURE ESTIMATES BASED ON BELEMNOIDS

Watanabe, Sayaka

http://hdl.handle.net/10026.1/5304

10.2110/palo.2014.106

PALAIOS

Society for Sedimentary Geology

All content in PEARL is protected by copyright law. Author manuscripts are made available in accordance with publisher policies. Please cite only the published version using the details provided on the item record or document. In the absence of an open licence (e.g. Creative Commons), permissions for further reuse of content should be sought from the publisher or author. 


\title{
ISOTOPIC ANALYSIS OF JURASSIC (CALLOVIAN) MOLLUSKS FROM THE CHRISTIAN MALFORD LAGERSTÄTTE (UK): IMPLICATIONS FOR OCEAN WATER TEMPERATURE ESTIMATES BASED ON BELEMNOIDS
}

\author{
GREGORY D. PRICE ${ }^{1 *}$, MALCOLM B. HART ${ }^{1}$, PHILIP R. WILBY ${ }^{2} \&$ KEVIN N. PAGE ${ }^{1}$ \\ ${ }^{1}$ School of Geography, Earth \& Environmental Sciences, Plymouth University, Drake Circus, \\ Plymouth PL4 8AA, Uk g.price@plymouth.ac.uk \\ ${ }^{2}$ British Geological Survey, Keyworth, Nottingham NG12 5GG, UK \\ *Corresponding Author
}

RRH: ISOTOPES FROM JURASSIC MOLLUSKS

LLH: PRICE, HART, WILBY \& PAGE

Keywords: Jurassic, belemnites, Belemnotheutis, paleoclimate, exceptional preservation

\begin{abstract}
Isotopic data ( $\mathrm{C}$ and $\mathrm{O}$ ) derived from Callovian (Middle Jurassic) mollusks (bivalves, ammonites and belemnoids, including true belemnites and Belemnotheutis) are presented from a narrow stratigraphic interval in the Christian Malford Lagerstätte, UK. The exceptionally well-preserved mollusks include aragonite-calcite pairs precipitated by individual belemnite animals that enable an assessment of possible "vital" effects and the reliability of using belemnite calcite to determine ocean water compositions. The oxygen isotope data derived from the calcitic rostra of the belemnites (Cylindroteuthis) show modest variability, ranging from -1.2 to $0.9 \%$ (V-PDB), while their accompanying aragonitic phragmocones range from -1.4 to $0.0 \%$. Data derived from the ammonite Kosmoceras show some scatter, with oxygen isotope values varying from -3.6 to $-0.2 \%$. The aragonite data from Cylindroteuthis, Kosmoceras and Belemnotheutis all overlap, suggesting they inhabited similar (surface) water depths. However, the corresponding data from the calcitic rostra of the Cylindroteuthis specimens suggest temperatures $\sim 5^{\circ} \mathrm{C}$ cooler. As we have analyzed aragonite-calcite pairs, the discrepancy cannot be explained by environmental effects. Though clearly a vital effect, it is difficult to resolve whether the temperatures derived from the aragonite (phragmocone) are too warm or from the calcite (rostrum) are too cool. Consequently, the applicability of standard paleotemperature equations to Cylindroteuthid belemnite rostra remains unproven. Sequentially sampled ontogenetic isotope data derived from Belemnotheutis phragmocones reveal only modest $\delta^{18} \mathrm{O}$ variation, consistent with limited movement between warmer (shallower) and cooler (deeper) waters. A coincidental systematic pattern of $\delta^{13} \mathrm{C}$ enrichment may signal changes in metabolic activity associated with a shift in ecology or feeding with age.
\end{abstract}




\section{INTRODUCTION}

The stable isotope (carbon and oxygen) geochemistry of biogenic carbonate can provide a reliable record of the environmental conditions experienced by aquatic organisms (e.g., Wright, 1987; Hudson et al., 1995; Cochran et al., 2010; Price and Teece, 2010; Lazo et al., 2008; Alberti et al., 2012) as well as insights into the paleoecology of the organisms themselves (e.g. Zakharov et al., 2006a; Lukeneder et al., 2010; Henderson and Price, 2012; Mettam et al., 2014). Accurate interpretation of the records is not only dependant on excellent fossil preservation, but also on an understanding of the dynamics of isotope fractionation in organisms, i.e. isotopic disequilibria often termed "vital effects". In general, mollusks are not considered to exert vital effects (e.g., Urey et al., 1951), a view supported by studies of shells secreted in modern oceans (e.g., Bettencourt and Guerra, 1999; Landman et al., 1994; Auclair et al., 2004). However, differences in the interpretation of the isotopic composition of fossil inoceramid bivalves, for example, has prompted debate regarding the validity of this assumption (e.g., Tourtelot and Rye, 1969; Wright, 1987; Fisher and Arthur, 2002; Zakharov et al., 2006a; Henderson and Price, 2012). Hence, there is a need to fully evaluate the potential for isotopic disequilibria between ambient waters and different polymorphs of biogenic carbonate (e.g., Lécuyer et al., 2012). In this study, previously proposed interpretations are re-evaluated in light of new isotopic data derived from a suite of exceptionally well-preserved Callovian (Middle Jurassic) mollusks from the Christian Malford Lagerstätte (Wilby et al., 2004; 2008; Tang, 2002). The Oxford Clay biota has been the subject of extensive previous isotopic work (e.g. Hudson, 1978; Anderson et al. 1994; Mettam et al., 2014). For example, Anderson et al. (1994), suggested, on the basis of stable isotope data, that belemnites (Cylindroteuthis) were nektobenthonic. Such an assertion has added significance as oxygen isotopes derived from belemnites are a widely used standard to determine Jurassic temperatures (Rosales et al., 2004; Price and Page, 2008; Wierzbowski, 2004; Wierzbowski et al., 2009; Dera et al. 2011; Alberti et al., 2012; Mettam et al., 2014). Preservation of original nacreous aragonite characterizes much of the diverse molluskan fauna (Duff, 1975; Martill and Hudson, 1991; Wilby et al., 2008) which includes denizens of both benthonic (bivalves, gastropods) and nektonic realms (ammonites). Also present are belemnites preserving both the calcitic rostrum and aragonitic phragmocone, allowing direct comparison of the two polymorphs. As well as assessing the isotopic variability of the assemblage to provide new data on potential isotope fractionation and the paleobiology of the mollusks, the climate of the Middle Jurassic is also evaluated through paleotemperature estimates in this study.

\section{GEOLOGICAL SETTING}

All of the samples for this study were obtained from a $2 \mathrm{~m}$ interval in the Phaeinum Subzone (Athleta Zone) of the Middle Jurassic (Callovian) Peterborough Member of the Oxford Clay Formation at Christian Malford, Wiltshire (Fig. 1). The Peterborough Member typically consists of decimeter-scale alternations of fissile, organic-rich mudrock (up to $16.6 \mathrm{wt} . \%$ TOC) and massive, shelly, organic-poor mudrock (ca. 3-6\% wt.\% TOC). These facies record variations in the frequency and duration of anoxia in the water-column (Kenig et al., 1994, 2004), and are characterized by 
distinct fossil assemblages (Duff, 1975). At Christian Malford, the organic-rich intervals are dominated by nekton, especially the ammonite Kosmoceras phaeinum, and by plasters of the bivalves Bositra and Meleagrinella, whereas the organic-poor beds are dominated by diverse assemblages of infaunal and epifaunal bivalves (especially nuculaceans, such as Mesosacella) and gastropods (Dicroloma, Procerithium). Benthic foraminifera and scaphopods occur in abundance at a limited number of thin $(<0.5 \mathrm{~cm}$ ) horizons (see Hart et al., 2013), probably recording brief changes in water depth and oxygenation. Macroscopic wood fragments are common throughout (Wilby et al., 2008), but the majority of organic matter is composed of amorphous material of marine origin (Belin and Kenig, 1994; Kenig et al., 1994). Regional evidence suggests that the Peterborough Member was deposited in a relatively shallow (a few 10's of meters) epicontinental sea, linking the Tethys to the Boreal Ocean (e.g., Hudson and Martill, 1994).

The Christian Malford Lagerstätte has yielded thousands of specimens of exquisitely preserved ammonites and bivalves, but is best known for abundant articulated fish remains and mass accumulates of squid-like coleoid cephalopods with preserved soft-parts (Owen, 1844; Pearce, 1841; Donovan, 1983; Allison, 1988; Doyle and Shakides, 2004; Wilby et al., 2008; Glass et al., 2013). True belemnites are rare, but are nevertheless dominated by specimens (principally Cylindroteuthis) still retaining their delicate phragmocones and sometimes even their proostracums (Fig. 2a). In contrast, the phragmocones of Belemnotheutis antiquus, a belemnotheutina (Donovan and Crane 1992), are comparatively common, as are the pens (gladius) and soft-tissue remains of the probable decapod Mastigophora (Donovan, 1983). In combination, these taxa indicate that the environment supported a complex trophic structure which, elsewhere, is further supported by the presence of giant fish and marine reptiles (see Martill et al., 1994).

\section{MATERIALS and METHODS}

Biogenic aragonite was sampled from the phragmocones of 24 specimens of Belemnotheutis antiquus, 13 specimens of Cylindroteuthis, 37 shells of Kosmoceras grp phaeinum, and 20 valves of Mesosacella. Calcite was sampled from 18 rostra of Cylindroteuthis and 4 valves of the pendent inoceramic bivalve Parainoceramus. Ontogenetic sampling (i.e. sclerochronology) was only attempted for the six best-preserved Belemnotheutis phragmocones. These varied $10-30 \mathrm{~mm}$ in length, were up to $25 \mathrm{~mm}$ in maximum width, and possessed clearly defined camerae. Their much reduced rostra, present as a thin brown coloured surficial layer towards the apical end (see Doyle and Shakides, 2004), was avoided. Similarly, sampling of phragmocone (aragonite) - rostrum (calcite) pairs was restricted to those specimens of Cylindroteuthis (7 in total) in which coincidental growth of the two structures could be reasonably determined.

Prior to chemical and isotopic analysis, samples were cleaned, where necessary, in an ultrasonic bath in order to remove any adherent matrix. Polished thin sections were prepared from one-half of the sample in order to undertake initial screening using a MK5 CITL cathodoluminescence $(\mathrm{CL})$ instrument. Belemnite and Parainoceramus samples were additionally analysed for trace element contents in order to identify any diagenetic alteration. For this, subsamples weighing 2-4 mg were dissolved in nitric acid and analyzed using a Varian 725-ES ICP-AES. 
Based upon analysis of duplicate samples, element concentrations were reproduced at better than $\pm 3 \%$. Selected aragonite samples of shell were also examined by $X$-ray diffraction (XRD), using a Philips Diffractometer to confirm shell mineralogy and to detect the presence and quantity of any secondary (diagenetic) calcite.

For stable isotope analyses (see Supplementary Data 1), between 200 and $400 \mu \mathrm{g}$ of carbonate powder were reacted with $100 \%$ phosphoric acid at $90{ }^{\circ} \mathrm{C}$ for approximately $1 \mathrm{~h}$ with a Gilson Multiflow carbonate auto-sampler. The $\mathrm{CO}_{2}$ produced was analysed on an Isoprime Instruments continuous flow mass spectrometer and the results were calibrated against Vienna Peedee Belemnite (V-PDB) using the NBS-19 international standard. The standard was evenly distributed throughout the individual isotope runs to correct for drift. The mean standard deviation on replicate analyses was in the order of $0.2 \%$ for both $\delta^{13} \mathrm{C}$ and $\delta^{18} \mathrm{O}$.

\section{RESULTS}

Fossil Preservation

Many studies regarding the isotope geochemistry of calcite mollusk shells have used $\mathrm{Sr}, \mathrm{Fe}$, $\mathrm{Mg}$ and $\mathrm{Mn}$ contents in conjunction with CL microscopy, to identify diagenetically altered samples (e.g., Rosales et al., 2004; Price and Teece, 2010; Wierzbowski, 2004; Alberti et al., 2012). This reduces the emphasis upon a single technique to discard affected samples. Recent shells and wellpreserved fossils typically show low concentrations of Fe and $\mathrm{Mn}$, and higher concentrations of $\mathrm{Mg}$ and Sr. Concentrations of Fe and $\mathrm{Mn}$ are typically higher in diagenetically altered calcites because $\mathrm{Fe}^{2+}$ and $\mathrm{Mn}^{2+}$ are more soluble under reducing conditions, and thus have a greater potential for substituting $\mathrm{Ca}^{2+}$ in the calcite lattice (Veizer, 1983). Conversely, post-depositional recrystallization typically causes a loss of $\mathrm{Mg}$ and $\mathrm{Sr}$ in skeletal calcite, so that their concentrations can provide further evidence for diagenetic alteration. The primary incorporation of $\mathrm{Mg}$ and $\mathrm{Sr}$ into biogenic carbonates is controlled by a variety of metabolic processes that govern precipitation rate, and also by environmental factors, such as variations in the seawater salinity and temperature (e.g., Klein et al., 1996; Stecher et al., 1996; Ullmann et al., 2013).

The ranges of concentrations of trace elements in well preserved belemnite rostra are reasonably well established. They typically have low concentrations of $\mathrm{Mn}(<100$ ppm) and Fe (<200 ppm) (e.g., Wierzbowski, 2004; Price et al., 2009a), and higher and more variable concentrations of Mg ( 1800-6000 ppm) and Sr ( 800-1600 ppm) (e.g., Wierzbowski, 2004; Price et al., 2009a; Alberti et al., 2012), presumably as a result of metabolic processes (e.g., see Morrison and Brand, 1986). Diagenetically unaltered low-Mg calcite (i.e., primary biogenic) typically appears nonluminescent, whereas the diagenetic incorporation of $\mathrm{Mn}^{2+}$ into the calcite lattice acts as an activator of an orange-colored luminescence, which is quenched by the incorporation of large concentrations of $\mathrm{Fe}^{2+}$. Most of the Christian Malford rostra are predominantly non-luminescent (Fig. 3c, d), consistent with them being well preserved (e.g. Barbin, 2013). Thin luminescent zones on their margins and around their apical zones were avoided during subsampling. The analysed Parainoceramus specimens have a thick calcitic prismatic shell layer with trace element values broadly comparable to those reported in well preserved inoceramids elsewhere (e.g., Pirrie and 
Marshall, 1990; Elorza and Garcia-Garmilla, 1996), although one sample shows elevated Fe content and both samples analysed showed very much reduced Mg concentrations (Supplementary Data 1).

SEM imaging (Fig. 3a, b) and XRD analysis similarly confirms the exceptional preservation of the aragonitic fossil specimens (Duff, 1975; Wilby et al., 2008). They all consist of stacked hexagonal tablets, typical of pristine aragonite (confirmed by XRD analysis) and lack evidence of intervening diagenetic cements. Such preservation is equivalent to the 'excellent' preservation of Cochran et al. (2010), and is comparable to the ultrastructure of the living Nautilus pompilius (e.g., Velazquez-Castillo et al., 2006).

Isotope results

The oxygen isotope values for the belemnite rostra (calcite) show only modest variability (Fig. 4), ranging from -1.2 to $0.9 \%$ (V-PDB). The corresponding carbon isotope values range from 0.5 to $3.2 \%$. Isotope data from their phragmocones (aragonite) show an overlapping range, whereby oxygen isotopes vary from -1.4 to $0.0 \%$ and carbon from -0.4 to $2.0 \%$. The isotope data derived from Mesosacella (aragonite) also overlap and range from -0.7 to $0.5 \%$ o for oxygen and 0.2 to $3.2 \%$ for carbon. In contrast, the isotope data derived from Parainoceramus (calcite) plot in a distinct field: oxygen isotope values range from -4.4 to $-3.7 \%$ and carbon from 4.0 to $6.9 \%$. Such negative oxygen and positive carbon values appear to be typical of inoceramids (e.g., Pirrie and Marshall 1990; He et al., 2005; Henderson and Price, 2012). We view the isotopic values for Parainoceramus as anomalous and ascribe them to a taxon-specific disequilibrium (i.e. vital effect). The data derived from Kosmoceras grp phaeinum (aragonite) show some scatter, with oxygen isotopes varying from -3.6 to $-0.2 \%$ and carbon isotopes varying from 1.7 to $4.6 \%$.

The isotope data derived from successive camerae of Belemnotheutis (aragonite) show a broad range, whereby oxygen isotopes vary from -2.7 to $0.1 \%$ ond carbon from -4.0 to $2.0 \%$ o (Fig. 4). Their ontogenetic $\delta^{13} \mathrm{C}$ profiles start with values typically between $-3.0 \%$ and $-2.0 \%$, and increase to more positive values between $-2.0 \%$ and $1.0 \%$ (in the portions of the shell formed later). In contrast, the $\delta^{18} \mathrm{O}$ profiles show only modest variability about the mean (Fig. 5).

\section{DISCUSSION}

\section{Isotopic variation in Cylindroteuthis}

The paired isotopic record in Cylindroteuthis helps inform understanding about the differences in isotope fractionation between aragonite and water and calcite and water. Carbon isotopic fractionation in laboratory-synthesized carbonates (e.g. Rubinson and Clayton, 1969; Romanek et al., 1992) have shown an enrichment in aragonite compared to calcite. For example, Romanek et al. (1992) found, on average, a 1.7\%o enrichment in aragonite compared to laboratorysynthesized calcite. Likewise, a number of authors (e.g., Eisma et al., 1976; Krantz et al., 1987; Lécuyer et al., 2012; Henderson and Price, 2012) have also noted that $\delta^{13} \mathrm{C}$ values in aragonitic organisms are generally more enriched than in coexisting calcitic organisms. The opposite relationship consistently exists in the aragonite-calcite pair data derived from Cylindroteuthis, which shows the $\delta^{13} \mathrm{C}$ of calcite to be enriched on average by $1.4 \%$ (range 0.6 to $2.0 \%$ ) relative to the aragonite (Fig. 6a). Using a Student T-test this difference is statistically significant at at $p<0.05$. 
Where different co-occurring aragonitic and calcitic organisms have been analyzed elsewhere, the differences in $\delta^{13} \mathrm{C}$ have been referred to differences in habitat or food source (e.g., Anderson et al., 1994; He et al., 2005; Fisher and Arthur, 2002; Price and Page, 2008; Price et al., 2009a). As we have analyzed aragonite-calcite pairs precipitated within individual animals (and therefore within the same water mass), environmental effects can be dismissed. Apart from some uncertainty regarding the exact synchronicity of each sample pair, the differences could potentially relate to metabolic effects resulting in differences in the internal dissolved inorganic carbon (DIC) of the microenvironments associated with the precipitation of aragonite versus calcite, leading to more isotopically light respired carbon incorporated into the aragonite part of the shell.

A small systematic difference is also seen in the paired $\delta^{18} \mathrm{O}$ data for Cylindroteuthis, with the calcite being more positive than the aragonite by an average of $0.5 \%$ o (ranging from just 0.0 upto $1.5 \%$, see Fig. 6a). Using a Mann-Whitney test this difference is statistically significant at at $p$ $\leqslant 0.05$. This contrasts with the results of certain abiotic/synthetic precipitation experiments (e.g., Tarutani et al., 1969; Kim and O'Neil, 1997; Kim et al., 2007), in which calcite was found to be depleted in ${ }^{18} \mathrm{O}$ by about 0.6 to $1.0 \%$ relative to aragonite. In agreement with these experiments, Grossman (1984) observed that the aragonitic benthic foraminiferan Hoeglundina elegans is enriched relative to the equilibrium value for calcite by $0.78 \pm 0.19 \%$. More recently, Kruta et al. (2014) also observed that the aragonitic shell of the ammonite Baculites sp., from the Pierre Shale (Upper Cretaceous) of South Dakota, is enriched relative to coexisting calcitic aptychi. Theoretical calculations (Zheng, 1999; Zhou and Zheng, 2003), however, and some field observations (e.g., Horibe and Oba, 1972), suggest calcite is ${ }^{18} \mathrm{O}$-enriched relative to aragonite, and Epstein et al. (1953) noted a slight tendency for ${ }^{18} \mathrm{O}$ to be concentrated in calcite relative to aragonite in their dataset. Thébault et al. (2007) investigated the oxygen isotope composition of scallops (Comptopallium radula) collected live in New Caledonia and in comparison with previously published empirical paleotemperature equations (Epstein et al., 1953) suggested that $C$. radula calcite is enriched in ${ }^{18} \mathrm{O}$ relative to equilibrium. In a more recent study, Lécuyer et al. (2012) analyzed carbon and oxygen isotope fractionations between calcite and aragonite in modern marine gastropods and bivalves living under temperate to tropical climates. They observed that although biogenic aragonite was typically ${ }^{18} \mathrm{O}$ enriched relative to co-existing biogenic calcite, most of the difference was due to variation in the acid fractionation factors of the polymorphs during the acid digestion preparations; that is, it was an analytical artifact. Finally, studies concerning both the aragonite nacreous part and co-precipitated calcitic parts of inoceramid bivalves (Tourtelot and Rye, 1969; Henderson and Price, 2012) show very little difference between oxygen isotope values.

According to the equations of Grossman and Ku (1986) for aragonite, and Anderson and Arthur's (1983) revision of the Epstein et al. (1953) equation for calcite, our calcite-aragonite paired data give an average temperature difference of $\sim 6^{\circ} \mathrm{C}$ (range $4-9^{\circ} \mathrm{C}$ ). A slightly reduced difference is given if the entire dataset is considered. It is difficult to resolve whether the temperatures derived from the aragonite are too warm, or the calcite data are too cool. However, data derived from Cylindroteuthis rostra (in particular) do often appear too cool, and have led some authors (e.g., Anderson et al., 1994; Zakharov et al., 2006a; Wierzbowski et al., 2009; Alberti et al., 2012; Mettam 
et al., 2014) to invoke nektobenthonic ecologies, migrations from cooler regions and/or deep water niches to account for the difference. Mettam et al. (2014), for example, interpreted the cooler $\delta^{18} \mathrm{O}$ paleotemperatures returned by Cylindroteuthis in the Peterborough Member in comparison to cooccurring Gryphaea as evidence for long-distance migration.

Isotope data from benthic fauna at Christian Malford may be instructive here. Oxygen isotope data from Mesosacella (aragonite), which lived infaunally, translate into a temperature range of 14 to $17^{\circ} \mathrm{C}$ (mean $16^{\circ} \mathrm{C}$ ) (Fig. $6 \mathrm{~b}$ ) if we assume a $\delta^{18} \mathrm{O}$ of $-1 \%$ for non-glacial seawater (see below). This is a little warmer than the accompanying belemnite calcite data, despite the fact that the bivalves can reasonably be interpreted to have inhabited a cooler (benthic) niche. One theoretical explanation for this relationship involves temperature inversions or water column overturn, though this was rejected by Mettam et al. (2014) for comparable data from the Peterborough Member. The Anderson and Arthur (1983) equation for calcite may not be applicable to Cylindroteuthid rostra. If the Thébault et al. (2007) empirical paleotemperature equation, derived from $C$. radula calcite, is applied to the Cylindroteuthis data apparent temperatures are raised by $\sim 3^{\circ} \mathrm{C}$ closing the gap a little. Alternatively, the Grossman and Ku (1986) equation for aragonite may not be applicable to their phragmocones. However, the Belemnotheutis and $K$. grp phaeinum data show trends very similar to the Cylindroteuthis phragmocone data (Fig. 6b), so the latter possibility appears less likely. Of course, it cannot be excluded that the Grossman and Ku (1986) equation for aragonite is not applicable to these organisms as well.

Several processes have been suggested to explain observed, non-equilibrium, isotopic signatures in molluscan shells (e.g., Tourtelot and Rye, 1969; McConnaughey, 1989; Owen et al., 2002). Metabolic effects (see below) may result in the introduction of isotopically depleted respiratory $\mathrm{CO}_{2}$ into the shell. With respect to Cylindroteuthis, the phragmocones represent gasfilled buoyancy structures, so it is conceivable that the gas in the vicinity of the phragmocone may have influenced carbonate chemistry at the site of mineralization. Alternatively, or additionally, kinetic isotope effects may occur. These generally discriminate against the heavier isotope; thus, rapidly secreted biogenic carbonates typically have lower $\delta^{18} \mathrm{O}$ values than the expected equilibrium value (e.g., McConnaughey, 1989). Following this reasoning would imply that Cylindroteuthis precipitated its phragmocone more rapidly than its rostrum, in apparent agreement with the intermittent (i.e. punctuated) growth envisaged for chambered mollusks.

\section{Paleoecology of Belemnotheutis}

The paleoecology of Belemnotheutis is poorly resolved, except that at least part of its diet consisted of other coleoids and teleost fish, that it was gregarious, and that it was probably an inshore species (Wilby et al., 2004). If equilibrium precipitation holds true for Belemnotheutis, then its ontogenetic record of $\delta^{18} \mathrm{O}$ should reflect water temperature variation (applying the equation of Grossman and $\mathrm{Ku}, 1986)$ and/or variation in the $\delta^{18} \mathrm{O}$ of the seawater $\left(\delta^{18} \mathrm{O}_{\text {seawater }}\right)$ in which it lived. It is not easy to determine precisely the $\delta^{18} \mathrm{O}_{\text {seawater }}$ of Callovian seawater, but if we assume a relatively constant value (e.g. - $1 \%$ o, an average for non-glacial seawater), the $\delta^{18}$ O data suggest that it occupied water varying between $5-8^{\circ} \mathrm{C}$ (with the exception of one sample). This contrasts 
markedly with ontogenetic changes in $\delta^{18} \mathrm{O}$ values within the modern Nautilus pompilius (Taylor and Ward, 1983; Zakharov et al., 2006b) which show a marked increase in oxygen isotopic composition between embryonic and post-embryonic stages, recording its migration from relatively warm, shallow waters into colder, deeper waters (Zakharov et al., 2006b). The limited change between the juvenile and adult stages of Belemnotheutis suggests that they did not inhabit dramatically different water masses during ontogeny, consistent with their inshore ecology based on observed distribution.

In contrast, a systematic ontogenetic pattern is prominent in the carbon isotope data, whereby the $\delta^{13} \mathrm{C}$ profiles increase from a minimum of -3.8\%o to a maximum of $1.6 \%$ o (see Fig. 5). Interpretation of these trends is challenging because the carbon used for shell building can be potentially derived from a number of different sources. 'Normal' oceans typically have a vertical isotopic gradient in which the surface waters are characterised by DIC with positive $\delta^{13} \mathrm{C}$ values ( 1$2 \%$ ), and the deeper waters have DIC with less positive values ( 0\%) (Kroopnick, 1985). Explaining the lighter $\delta^{13} \mathrm{C}$ values in the more juvenile parts of Belemnotheutis phragmocones in terms of greater freshwater influence at this time is rejected based on the absence of a corresponding signal in the $\delta^{18} \mathrm{O}$ values. Instead, we consider the consistently negative carbon isotope values in this part of the phragmocone more likely reflects a disequilibria (or vital fractionation) effect. These are believed to be related to kinetic effects associated with $\mathrm{CO}_{2}$ hydration, or to metabolic effects resulting from changes in the internal dissolved inorganic carbon in the vicinity of the precipitating carbonate (McConnaughey, 1989). Comparable non-equilibrium carbon isotope fractionation has been reported in modern cephalopods, such as Nautilus macromphalus (Auclair et al., 2004), Sepia officinalis (Bettencourt and Guerra, 1999; Rexfort and Mutterlose, 2006) and Spirula spirula (Lukeneder et al., 2008; Price et al., 2009b). The incorporation of negative $\delta^{13} \mathrm{C}$ from metabolic $\mathrm{CO}_{2}$ results in a ${ }^{13} \mathrm{C}$ depleted shell compared to carbonate in equilibrium with the DIC of seawater, and may be a consequence of a change in metabolism and/or the utilization of food sources with different ${ }^{13} \mathrm{C}$ signatures (e.g., Cherel and Hobson, 2005; Gillikin et al., 2007). Certainly, factors such as metabolic activity and food source influence ${ }^{13} \mathrm{C}$ to a greater extent than it does $\delta^{18} \mathrm{O}$, accounting for the lack of correlation between oxygen and carbon isotope trends (Fig. 5).

Ontogenetic decreases in $\delta^{13} \mathrm{C}$ (i.e. the opposite trend to Belemnotheutis) have been observed in many bivalves (e.g., Krantz et al., 1987; Lorrain et al., 2004) and in Nautilus shells (e.g., Auclair et al., 2004), where it has been linked to a greater proportion of ${ }^{13} \mathrm{C}$-depleted metabolic carbon being incorporated into the shell due to an increase in metabolic rate relative to growth (e.g., Gillikin et al., 2007). However, incorporation of increasingly more metabolic carbon through ontogeny may not be a general model for all mollusks. Indeed, some studies recorded no discernible $\delta^{13} \mathrm{C}$ decrease (e.g., Buick and Ivany, 2004; Gillikin et al., 2005; Alberti et al., 2013). The prevalence of lower carbon isotope values in the early growth stages of fish otoliths has also been attributed to more metabolic $\mathrm{CO}_{2}$ being available at this point, with a subsequent decrease in metabolic influence during later growth, and hence an increase in biomineral $\delta^{13} \mathrm{C}$ (towards the isotopic signature of the DIC) (e.g., Schwarcz et al., 1998). Such ontogenetic trends in $\delta^{13} \mathrm{C}$ of fish otoliths have been related to a shift from pelagic feeding to relatively sedentary, benthic feeding 
(e.g., Sherwood and Rose, 2003). The trends seen in Fig. 5 are difficult to reconcile with such a shift in ecology, because both large and small specimens of Belemnotheutis are found preserved alongside one another, so presumably they formed shoals of mixed age, as many squid do today. Hence, it would appear that Belemnotheutis does not incorporate increasingly more metabolic DIC through ontogeny (cf. Lorrain et al., 2004). More likely, a change in the internal DIC pool could have been caused by differences in the food sources utilized during ontogeny, with each having very different $\delta^{13} \mathrm{C}$ signatures (e.g., Gillikin et al., 2007).

The oxygen and carbon data for Belemnotheutis phragmocones overlap with that of the Cylindroteuthis phragmocones (aragonite), as well as with Kosmoceras grp phaeinum (see Fig. 4). Accepting the data from the aragonite as a faithful record, this suggests that these animals occupied similar niches in terms of temperature (Fig. 6b), distinctly different from the benthic temperatures (as derived from the Mesosacella). Hence, rather than Cylindroteuthis being nektobenthonic (cf. Anderson et al., 1994; Wierzbowski et al., 2009) or strongly migratory (Zakharov et al., 2006a; Alberti et al., 2012; Mettam et al., 2014), as inferred from its calcitic rostrum, the results of isotopic analysis raise the possibility that it inhabited surface waters, avoiding the intermittently inhospitable (anoxic or dysoxic) sea floor environment (see Wilby et al., 2008).

\section{Implications for paleoclimate}

Palaeoclimate models for the Jurassic (e.g., Sellwood and Valdes, 2006) point to more or less equable climatic conditions, although the existence of major climatic perturbations is implied by the temperature curve developed by Dera et al. (2011). In particular, a glacial phase connected to a global sea-level low and temperature minimum has been proposed for the Middle to Late Jurassic transition (Dromart et al., 2003), which immediately post-dates the deposition of the Peterborough Member. However, this is not supported by a number of isotope studies of belemnites (e.g., Wierzbowski et al., 2009; Alberti et al., 2012) that show no distinct positive $\delta^{18} \mathrm{O}$ anomaly that could be linked to a potential glacial phase. While the data from our study cannot be used to define longer term trends, they do point to moderate warmth during the Athleta Zone (i.e., at the same time as the inferred ice age at the Middle-Late Jurassic transition).

\section{CONCLUSIONS}

Our isotopic study of well-preserved Callovian mollusk shells (belemnoids, ammonites and bivalves) from the Christian Malford Lagerstätte reveals the significant influence of mineral polymorph (aragonite vs. calcite) upon resulting ecological interpretations. Oxygen isotope analyses of calcitic belemnite rostra generally concur with a benthic mode of life or migratory mode of life. Conversely, the isotopic signatures derived from their aragonitic phragmocones suggest a surface water ecology, similar to the co-occurring ammonites and Belemnotheutis. Although we have analyzed calcite-aragonite pairs precipitated by individual belemnite animals, it is not possible to definitively resolve whether the temperatures derived from the calcite (rostrum) data are too cool, or from the aragonite (phragmocone) data are too warm. Consequently, without an independent 
temperature measure it is not possible to determine whether the paleotemperature equations for calcite or aragonite are applicable to Cylindroteuthid belemnites and, hence, how reliable paleotemperatures based on them are. Sequentially sampled ontogenetic isotope data derived from Belemnotheutis phragmocones reveal only modest $\delta^{18} \mathrm{O}$ variation, consistent with limited migration between warmer (shallower) and cooler (deeper) waters. A systematic ontogenetic pattern is present in the associated carbon isotope data, with $\delta^{13} \mathrm{C}$ enrichment in mature specimens. This pattern may be indicative of changes in metabolic activity, although most mollusks show the opposite ontogenetic trend. Hence, the model proposed by Lorrain et al. (2004), whereby bivalves incorporate increasingly more metabolic DIC through ontogeny, appears not to fit with Belemnotheutis.

\section{Acknowledgements}

The authors acknowledge the financial assistance provided by the Curry Fund of the Geologists' Association, the British Geological Survey University Funding Initiative and the S.W. Regional Group of the Geological Society. Particular thanks go to the land owner at Christian Malford for allowing us access; to John Hudson, Keith Duff and Roy Clements for very useful discussion; to Sue Martin for assistance with collecting and diligent curation; and to Steve Thorpe and Ricky Terrington for undertaking the associated drilling campaign. The manuscript benefited from the constructive comments of two anonymous reviews in addition to suggestions made by the PALAIOS editor.

\section{References}

Alberti, M., FÜRsICH, F.T., and PANDEY, D.K., 2012, The Oxfordian stable isotope record $\left(\delta^{18} \mathrm{O}, \delta^{13} \mathrm{C}\right)$ of belemnites, brachiopods, and oysters from the Kachchh Basin (western India) and its potential for palaeoecologic, palaeoclimatic, and palaeogeographic reconstructions: Palaeogeography, Palaeoclimatology, Palaeoecology: v. 344-345, p. 49-68.

AlberTI, M., Fürsich, F.T., and PANDEY, D.K. 2013, Seasonality in low latitudes during the Oxfordian (Late Jurassic) reconstructed via high-resolution stable isotope analysis of the oyster Actinostreon marshi (J. Sowerby, 1814) from the Kachchh Basin, western India: International Journal of Earth Sciences, v. 102, p. 1321-1336.

AlLISON, P.A., 1988, Phosphatized soft-bodied squids from the Jurassic Oxford Clay: Lethaia, v. 21, p. 403-410.

Anderson, T.F., and ARthUR, M.A., 1983, Stable isotopes of oxygen and carbon and their application to sedimentologic and environmental problems. in Arthur, M.A., Anderson, T.F., Kaplan, I.R., Veizer, J., and Land, L.S. eds., Stable Isotopes in Sedimentary Geology. SEPM Short Course Notes, v. 10, p. 1.1-1.151. 
Anderson, T.F., Popp, B.N., Williams, A.C., Ho, L.Z., and HudSON, J. D., 1994. The stable isotopic records of fossils from the Peterborough Member, Oxford Clay Formation (Jurassic), U.K.:

Palaeoenvironmental implications: Journal of the Geological Society, London, v. 151, p. 125138.

Auclair, A.C., Lécuyer, C., Bucher, H., and Sheppard, S.M.F., 2004, Carbon and oxygen isotope composition of Nautilus macromphalus: a record of thermocline waters off New Caledonia: Chemical Geology, v. 207, p. 91-100.

BARBIN, V., 2013. Application of cathodoluminescence microscopy to recent and past biological materials: a decade of progress: Mineralogy and Petrology, v. 107, p. 353-362.

BeLIN, S., and KENIG, F., 1994, Petrographic analysis of organo-mineral relationships: Depositional conditions of the Oxford Clay Formation (Jurassic),UK: Journal of the Geological Society, London, v. 151, p. 153-160.

Bettencourt, V., and Guerra, A., 1999, Carbon- and oxygen-isotope composition of the cuttlebone of Sepia officinalis: a tool for predicting ecological information? Marine Biology, v. 133, p. 651-657.

BUICK, D.P., and IVANY, L.C., 2004, 100 years in the dark: extreme longevity of Eocene bivalves from Antarctica: Geology, v. 32, p. 921-924.

Cherel, Y., and Hobson, K.A., 2005, Stable isotopes, beaks and predators: A new tool to study the trophic ecology of cephalopods, including giant and colossal squids: Proceedings of the Royal Society, London, ser. B, v. 272, p. 1601-1607.

Cochran, J.K., Kallenberg, K., Landman, N.H., Harries, P.J., Weinreb, D., TurekiAn, K.K., Beck, A.J., and CobBAN, W.A., 2010, Effect of Diagenesis on the $\mathrm{Sr}$, O, and C isotope composition of Late Cretaceous Molluscs from the Western Interior Seaway of North America: American Journal of Science, v. 310, p. 69-88.

Dera, G., Brigaud, B., Monna, F., Laffont, R., Pucéat, E., Deconinck, J.-F., Pellenard, P., Joachimski, M.M., and DURLET, C., 2011, Climatic ups and downs in a disturbed Jurassic world: Geology, v. 39 , p. $215-218$.

Donovan, D.T., 1983, Mastigophora Owen 1856: a little known genus of Jurassic coleoids: Neues Jahrbuch für Geologie und Paläontologie, Abhandlungen, v. 165, p. 484-495.

Donovan, D.T., and CRANE, M.D., 1992, The type material of the Jurassic cephalopod Belemnotheutis: Palaeontology, v.35, p. 273-296.

DoYLE, P., and SHAKIDES, E.V., 2004, The Jurassic belemnite suborder Belemnotheutina: Palaeontology, v. 47, p. 983-998. 
Dromart, G., Garcia, J.-P., Picard, S., Atrops, F., LÉCuyer, C., and Sheppard, S.M.F., 2003, Ice age at the Middle-Late Jurassic transition? Earth and Planetary Science Letters, v. 213, p. 205-220.

DUFF, K.L., 1975, Palaeoecology of a bituminous shale: the Lower Oxford Clay of central England: Palaeontology, v. 18, p. 443-482.

EISMA, D., Mook, W.G., and DAS, H.A., 1976, Shell characteristics, isotopic composition and trace element contents of some euryhaline molluscs as indicators of salinity: Palaeogeography Palaeoclimatology Palaeoecology, v. 19, p. 39-62.

ELORZA, J.J., and GARCIA-GARMILLA, F., 1996, Petrological and geochemical evidence for diagenesis of inoceramid bivalve shells in the Plenties Formation (Upper Cretaceous, Basque-Cantabrian region, northern Spain): Cretaceous Research, v. 17, p. 479-503.

EPSTEIN S., BUCHSBAUM, R., LOWENSTAM, H., and UREY, H.C., 1953, Revised carbonate-water isotopic temperature scale: Geological Society of America Bulletin, v. 64, p. 1315-1326.

FISHER, C.G., and ARTHUR, M.A., 2002, Water mass characteristics in the Cenomanian US Wester Interior seaway as indicated by stable isotopes of calcareous organisms: Palaeogeography, Palaeoclimatology, Palaeoecology, v. 188, p. 189-213.

Gillikin, D.P., De Ridder, F., Ulens, H., Elskens, M., Keppens, E., BAeyens, W., and DehaiRS, F., 2005, Assessing the reproducibility and reliability of estuarine bivalve shells (Saxidomus giganteus) for sea surface temperature reconstruction: implications for paleoclimate studies: Palaeogeography Palaeoclimatology Palaeoecology, v. 228, p. 70-85.

GilLIIIIN, D.P., LoRRaiN, A., MenG, L., and DehaiRs F., 2007, A large metabolic carbon contribution to the $\delta^{13} \mathrm{C}$ record in marine aragonitic bivalve shells: Geochimica et Cosmochimica Acta, v. 71, p. 2936-2946.

Glass, K., Ito, S., Wilby, P.R., Sota, T., Nakamura, A., Bowers, C.R., Vinther, J., Dutta, S., Summons, R., BRIGGS, D.E.G., WAKAMATSU, K., and SIMON, J.D. 2013, Direct chemical evidence for eumelanin pigment from the Jurassic period: PNAS, v. 109, p. 10218-10223.

Grossman, E.L., 1984, Stable isotope fractionation in live benthic foraminifera from the Southern California borderland: Palaeogeography Palaeoclimatology Palaeoecology, v. 47, p. 301-327.

Grossman, E.L., and Ku, T.-L., 1986, Oxygen and carbon isotope fractionation in biogenic aragonite. temperature effects: Chemical Geology, v. 59, p. 59-74.

Hart, M.B., De Jonghe, A., Rundle, A.J., and. SMART, C.W., 2013, Statoliths: neglected microfossils: Journal of Micropalaeontology, v. 32, p. 219-220. 
HE, S., KYSER, T.K., and CALDWELL, W.G.E., 2005, Paleoenvironment of the Western Interior Seaway inferred from $\delta^{18} \mathrm{O}$ and $\delta^{13} \mathrm{C}$ values of molluscs from the Cretaceous Bearpaw marine cyclothem: Palaeogeography, Palaeoclimatology, Palaeoecology, v. 217, p. 67-85.

Henderson, R.A., and PrICE, G.D., 2012, Paleoenvironment and paleoecology inferred from oxygen and carbon isotopes of subtropical mollusks from the Late Cretaceous (Cenomanian) of Bathurst Island, Australia: PALAIOS, v. 27, p. 617-626.

HORIBE, S., and ОвА, T., 1972,Temperature scales of aragonite-water and calcite-water systems: Fossils, v. 23/24, p. 69-79.

Hudson, J.D., 1978, Concretions, isotopes, and the diagenetic history of the Oxford Clay (Jurassic) of central England: Sedimentology, v. 25, p. 339-370.

Hudson, J.D., and MARTILL, D.M., 1994, The Peterborough Member (Callovian, Middle Jurassic) of the Oxford Clay Formation at Peterborough, UK: Journal of the Geological Society London, v. 151, p. 113-124.

Hudson, J.D., Clements, R.G., Riding, J.B., WAKefield, M.I., and WAlton, W., 1995, Jurassic paleosalinities and brackish-water communities: a case study: PALAIOS, v. 10, p. 392-407.

KENIG, F., HAYES, J.M., POPP, B.N., and SUMmONS, R.E., 1994, Isotopic biogeochemistry of the Oxford Clay Formation (Jurassic), UK: Journal of the Geological Society, London, v. 151, p. 139-152.

KenIG, F., Hudson, J.D., Sinninghe DAmstÉ, J.S., and Popp, B.N., 2004, Intermittent euxinia: Reconciliation of a Jurassic black shale with its biofacies: Geology, v. 32, 421-424.

KIM, S.T., and O'NEIL, J.R., 1997, Equilibrium and nonequilibrium oxygen isotope effects in synthetic carbonates: Geochimica et Cosmochimica Acta, v. 61, p. 3461-3475.

KIM, S.T., O'NEIL, J.R., HILLAIRE-MARCEL, C., and MUCCI, A., 2007, Oxygen isotope fractionation between synthetic aragonite and water: influence of temperature and $\mathrm{Mg}^{2+}$ concentration: Geochimica et Cosmochimica Acta, v. 71, p. 4704-4715.

KLEIN, R.T., LOHMANN, K.C., and THAYER, C.W., 1996, Bivalve skeletons record sea-surface temperature and ${ }^{18} \mathrm{O}$ via $\mathrm{Mg} / \mathrm{Ca}$ and ${ }^{18} \mathrm{O} /{ }^{16} \mathrm{O}$ ratios: Geology, v. 24, p. 415-418.

KRANTZ, D.E., WILLIAMS, D.F., and JONES, D.S., 1987, Ecological and paleoenvironmental information using stable isotope profiles from living and fossil mollusks: Palaeogeography Palaeoclimatology Palaeoecology, v. 58, p. 249-266.

KROOPNICK, P.M., 1985, The distribution of $\delta^{13} \mathrm{C}$ of $\Sigma \mathrm{CO}_{2}$ in the world ocean: Deep-Sea Research, v. 327, p. 57-84.

KRUtA, I., LANDMAN, N.H., and CoChran, J.K., 2014, A new approach for the determination of Ammonite and Nautilid habitats: PLoS One, 10.1371/journal.pone.0087479 
LANDMAN, N.H., Cochran, J.K., RYe, D.M., TANABE, K., and ARnold, J.M., 1994, Early life history of Nautilus: Evidence from isotopic analyses of aquarium-reared specimens: Paleobiology, v. 20, p. 40-51.

Lazo, D.G., Aguirre-Urreta, M. B., Price, G.D., Rawson, P.F., Ruffell, A.H., and Ogle, N., 2008, Palaeosalinity variations in the Early Cretaceous of the Neuquén Basin, Argentina: evidence from oxygen isotopes and detailed palaeoecological analysis: Palaeogeography Palaeoclimatology Palaeoecology, v. 260, p. 477-493.

Lécuyer, C., Hutzler, A., Amiot, R., Daux, V., Grosheny, D., Otero, O., Martineau, F., Fourel, F., Balter, V., and ReYNARD, B., 2012, Carbon and oxygen isotope fractionations between aragonite and calcite of shells from modern molluscs: Chemical Geology, v. 332-333, p. 92-101.

Lorrain, A., Paulet, Y.-M., Chauvaud, L., Dunbar, R., Mucciarone, D., and Fontugne, M., 2004, $\delta^{13} \mathrm{C}$ variation in scallop shells: increasing metabolic carbon contribution with body size: Geochimica et Cosmochimica Acta, v. 68, p. 3509-3519.

Lukeneder, A., Harzhauser, M., Müllegger, S., and Piller, W.E., 2008, Stable isotopes $\left(\delta^{18} \mathrm{O}\right.$ and $\left.\delta^{13} \mathrm{C}\right)$ in Spirula spirula shells from three major oceans indicate developmental changes paralleling depth distributions: Marine Biology, v. 154, p. 175-182, doi: 10.1007/s00227-008-0911-5.

Lukeneder, A., Harzhauser, M., Müllegger, S., and Piller, W.E., 2010, Ontogeny and habitat change in Mesozoic cephalopods revealed by stable isotopes $\left(\delta^{18} \mathrm{O}, \delta^{13} \mathrm{C}\right)$ : Earth and Planetary Science Letters, v. 296, p. 103-114.

MARTILL, D.M., and Hudson, J.D., 1991, Fossils of the Oxford Clay. Palaeontological Association Field Guide to Fossils: Number 4. pp 286.

MARTILL, D.M., TAYLOR, M. A., Duff, K.L., RIDING, J.B., and Bown, P.R., 1994, The trophic structure of the biota of the Peterborough Member, Oxford Clay Formation (Jurassic), UK: Journal of the Geological Society, London, v. 151, p. 173-194.

McConnaughey, T.A., $1989,{ }^{13} \mathrm{C}$ and ${ }^{18} \mathrm{O}$ isotopic disequilibrium in biological carbonates: II. In vitro simulation of kinetic isotope effects: Geochimica et Cosmochimica Acta, v. 53, p. 163-171.

Mettam, C., Johnson, A.L.A., Nunn, E.V., and SChÖne, B.R., 2014, Stable isotope ( $\delta^{18} \mathrm{O}$ and $\delta^{13} \mathrm{C}$ ) sclerochronology of Callovian (Middle Jurassic) bivalves (Gryphaea (Bilobissa) dilobotes) and belemnites (Cylindroteuthis puzosiana) from the Peterborough Member of the Oxford Clay Formation (Cambridgeshire, England): Evidence of palaeoclimate, water depth and belemnite behaviour: Palaeogeography, Palaeoclimatology, Palaeoecology, v. 399, p. 187201.

MoRRISON, J.O., and BRAND, U., 1986, Geochemistry of recent marine invertebrates: Geoscience Canada, v. 13 , p. 237-254 
OWEN, R., 1844, A description of certain belemnites, preserved, with a great proportion of their soft parts, in the Oxford Clay at Christian Malford, Wilts: Philosophical Transactions of the Royal Society, v. 125 , p. $65-85$.

OWEN, R., KENNEDY, H., and RICHARDSON, C., 2002, Experimental investigation into partitioning of stable isotopes between scallop (Pecten maximus) shell calcite and sea water: Palaeogeography, Palaeoclimatology, Palaeoecology, v. 185, p. 163-174.

PeARCE, J.C., 1841, On the mouths of ammonites, and on fossils contained in laminated beds of the Oxford Clay, discovered in cutting the Great Western Railway, near Christian Malford in Wiltshire: Proceedings of the Geological Society of London, v.3, p. 592-594.

PIRRIE, D., and MARShALL, J.D., 1990, Diagenesis of Inoceramus and late Cretaceous paleoenvironmental geochemistry; a case study from James Ross Island Antarctica: PALAIOS, v. 5, p. 336-345.

PRICE, G.D., and PAGE, K.N., 2008, A carbon and oxygen isotopic analysis of molluscan faunas from the Callovian-Oxfordian boundary at Redcliff Point, Weymouth, Dorset: implications for belemnite behaviour: Proceedings of the Geologists' Association, v. 119, p. 153-160.

PrICE, G.D., and TEECE, C., 2010, Reconstruction of Jurassic (Bathonian) palaeosalinity using stable isotopes and faunal associations: Journal of the Geological Society, London, v. 167, p. 11991208.

PrICE, G.D., WILKINSON, D., HART, M.B., PAGE, K.N., and GRIMES, S.T., 2009a, Isotopic analysis of coexisting late Jurassic fish otoliths and molluscs: implications for upper ocean water temperature estimates: Geology, v. 37, p. 215-218.

Price, G.D., TWitchett, R.J., Smale, C., and Marks, V., 2009b, Isotopic analysis of the life history of the enigmatic squid Spirula spirula, with implications for studies of fossil cephalopods: PALAIOS, v. 24, p. 273-279.

ReXfort, A., and Mutterlose, J., 2006, Stable isotope records from Sepia officinalis-a key to understanding the ecology of belemnites? Earth and Planetary Science Letters, v. 247, p. 212-221.

Romanek, C.S., Grossman, E.L., and Morse, J.W., 1992, Carbon isotopic fractionation in synthetic aragonite and calcite: effects of temperature and precipitation rate: Geochimica et Cosmochimica Acta, v. 56, p. 419-430.

Rosales, I., Robles, S., and QueSADA, S., 2004, Elemental and oxygen isotope composition of Early Jurassic belemnites: Salinity vs. temperature signals: Journal of Sedimentary Research, v. 74, p. 342-354. 
RUBINSON, M, and CLAYTON, R.N., 1969, Carbon-13 fractionation between aragonite and calcite:

Geochimica et Cosmochimica Acta, v. 33, p. 997-1002.

Schwarcz, H.P., Gao, Y., Campana, S., Browne, D., Knyf, M., and Brand U., 1998, Stable carbon isotope variations in otoliths of Atlantic cod (Gadus morhua): Canadian Journal of Fisheries and Aquatic Sciences, v. 55, p. 1798-1806.

SelLwOOD, B.W., and VALDES, P.J., 2006, Mesozoic climates: general circulation models and the rock record: Sedimentary Geology, v. 190, p. 269-287.

SHERWOOD, G.D., and ROSE, G.A., 2003, Influence of swimming form on otolith ${ }^{13} \mathrm{C}$ in marine fish. Marine Ecology Progress Series, v. 258, p. 283-289.

Stecher, H.A., Krantz, D.E., LoRd, C.J., Luther, G.W., and Bock, K.W., 1996, Profiles of strontium and barium in Mercenaria mercenaria and Spisula solidissima shells: Geochimica et Cosmochimica Acta, v. 60, p. 3445-3456.

TANG, C.M., 2002, Oxford Clay: England's Jurassic Marine Park. In: Exceptional Fossil Preservation: a unique view on the evolution of marine life (eds. Bottjer, D.J., Etter, W., Hagadorn, J.W. \& Tang, C.M.). Columbia University Press, New York, p. 308-325.

TARUtANI, T., Clayton, R.N., and MAYEDA, T.K., 1969, The effect of polymorphism and magnesium substitution on oxygen isotope fractionation between calcium carbonate and water: Geochimica et Cosmochimica Acta, v. 33, p. 987-996.

TAYLOR, B.E., and WARD, P.D., 1983, Stable isotope studies of Nautilus macromphalus Sowerby (New Caledonia) and Nautilus pompilius L. (Fiji): Palaeogeography Palaeoclimatology Palaeoecology, v. 41, p. 1-16.

Thébault, J., Chauvaud, L., Clavier, J., Guarini, J., Dunbar, R.B., Fichez, R., Mucciarone, D.A., and Morize, E., 2007, Reconstruction of seasonal temperature variability in the tropical Pacific Ocean from the shell of the scallop, Comptopallium radula: Geochimica et Cosmochimica Acta, v. 71, p. 918-928.

TOURTELOT, H.A., and RYE, R.O., 1969, Distribution of oxygen and carbon isotopes in the fossils of Late Cretaceous age, Western Interior region of North America: Geological Society of America Bulletin, v. 80, p. 1903-1922.

Ullmann, C.V., Hesselbo, S.P., and KorTe, C., 2013, Tectonic forcing of Early to Middle Jurassic seawater Sr/Ca: v. 41, p. 1211-1214.

UREY, H.C., LOWEnStAM, H.A., EPSTEIN, S., and McKinney, C.R., 1951, Measurement of paleotemperatures and temperatures of the Upper Cretaceous of England, Denmark, and the southeastern United States: Geological Society of America Bulletin, v. 62, p. 399-416. 
VEIZER, J., 1983, Chemical diagenesis of carbonates: Theory and application of trace element technique. in Arthur, M.A., Anderson, T.F., Kaplan, I.R., Veizer, J., and Land, L.S. eds., Stable isotopes in Sedimentary Geology. SEPM Short Course Notes, v. 10, p. 3.1-3.100.

Velazquez-Castillo, R.R., Reyes-Gasga, J ; Garcia-GutierRez, D.I., and Jose-Yacaman, M., 2006, Crystal structure characterization of nautilus shell at different length scales: Biomaterials, v. 27, p. 4508-4517.

WIERZBOWSKI, H., 2004, Carbon and oxygen isotope composition of Oxfordian-Early Kimmeridgian belemnite rostra: palaeoenvironmental implications for Late Jurassic seas: Palaeogeography, Palaeoclimatology, Palaeoecology, v. 203, p. 153-168.

Wierzbowski, H., Dembicz, K., and Praszkier, T., 2009, Oxygen and carbon isotope composition of Callovian-Lower Oxfordian (Middle-Upper Jurassic) belemnite rostra from central Poland: a record of a Late Callovian global sea-level rise? Palaeogeography Palaeoclimatology Palaeoecology, v. 283, p. 182-194.

WILBY, P.R., HUdSON, J.D., CLEMENTS, R.G., and HoluINGWORTH, N.T.J., 2004,Taphonomy and origin of an accumulate of soft-bodied cephalopods in the Oxford Clay Formation (Jurassic, England): Palaeontology, v. 47, p. 1159-1180.

WILBY, P.R., DufF, K., PAGE, K., and MARTIN, S., 2008, Preserving the unpreservable: a lost world rediscovered at Christian Malford, UK: Geology Today, v. 24, p. 95-98.

WRIGHT, E.K., 1987, Stratification and paleocirculation of the Late Cretaceous Western Interior Seaway of North America: Geological Society of America Bulletin, v. 99, p. 480-490.

Zakharov, Y.D., Smyshlyaeva, O.P., ShigetA, Y., Popov, A.M., and Zonova, T.D., 2006a, New data on isotopic composition of Jurassic-Early Cretaceous cephalopods: Progress in Natural Science, v. 16, p. $50-67$.

Zakharov, Y.D., ShigetA, Y., Smyshlyaeva, O.P., Popov, A.M., and IgnatieV, A.V., 2006b, Relationship between $\delta^{13} \mathrm{C}$ and $\delta^{18} \mathrm{O}$ values of the Recent Nautilus and brachiopod shells in the wild and the problem of reconstruction of fossil cephalopod habitat: Geosciences Journal, v. 10, p. 331-345.

ZHENG, Y.-F., 1999, Oxygen isotope fractionation in carbonate and sulfate minerals: Geochemical Journal, v. 33, p. 109-126.

ZHOU, G.-T., and ZHENG, Y.-F., 2003, An experimental study of oxygen isotope fractionation between inorganically precipitated aragonite and water at low temperatures: Geochimica et Cosmochimica Acta, v. 67, p. 387-399. 
Figure and Table Captions

Figure 1 Sketch map showing the occurrences of Callovian rocks in the UK and the location of the Christian Malford Lagerstätte.

Figure 2 Photographs of (a) a Cylindroteuthis rostrum with its accompanying phragmocone still associated, (b) and (c) near-complete Belemnotheutis phragmocones with their diminutive rostra visible at their proximal ends, (d) iridescent fragment of Kosmoceras grp phaeinum.

Figure 3 SEM photomicrographs of (a) wall of Belemnotheutis phragmocone (Sample PRW297), showing two prismatic layers, (b) nacreous layers in Cylindroteuthis phragmocone showing typical stacked arrangement of hexagonal tablets. (c) Plane polarized and (d) CL photomicrographs of a calcitic Cylindroteuthis rostrum (sample PRW233), indicating a lack of diagenetic alteration.

Figure 4. Cross plot of total $\delta^{18} \mathrm{O}$ and $\delta^{13} \mathrm{C}$ data from the Christian Malford Lagerstätte (note that $\delta^{18} \mathrm{O}$ decreases upwards).

Figure 5. Ontogenetic oxygen and carbon isotope profiles from Belemnotheutis phragmocones (open circles=carbon; filled circles=oxygen isotopes). The $x$-axis refers to the actual chamber numbers. For each plot the juvenile part of the phragmocone is to the left, and successive camera are numbered accordingly. Samples PRW552; PRW242; PRW527 and PRW523 represent near complete phragmocones, and gaps in ontogenetic profiles result from a lack of suitable preserved material.

Figure 6. Aragonite-calcite contrasts and temperature estimates. (a) Cross plot of $\delta^{18} \mathrm{O}$ and $\delta^{13} \mathrm{C}$ data from Cylindroteuthis. Aragonite-calcite pairs are given for seven specimens whose calcitic rostrum (filled circles) remained attached to its corresponding aragonitic phragmocone (filled triangles). Open circles and open triangles are un-paired rostra and phragmocones, respectively. (b) Summary of paleotemperature interpretations using a $\delta^{18} \mathrm{O}$ seawater value of $-1.0 \%$ and the equations of Grossman and $\mathrm{Ku}$ (1986) for aragonite, and Anderson and Arthur (1983) for calcite fossils. The Cylindroteuthis rostrum and Cylindroteuthis phragmocone interpretations are derived from the aragonite-calcite pair data. Open circles = aragonitic organisms; filled circle = calcitic organism .

Appendix 1 Summary of isotopic data 

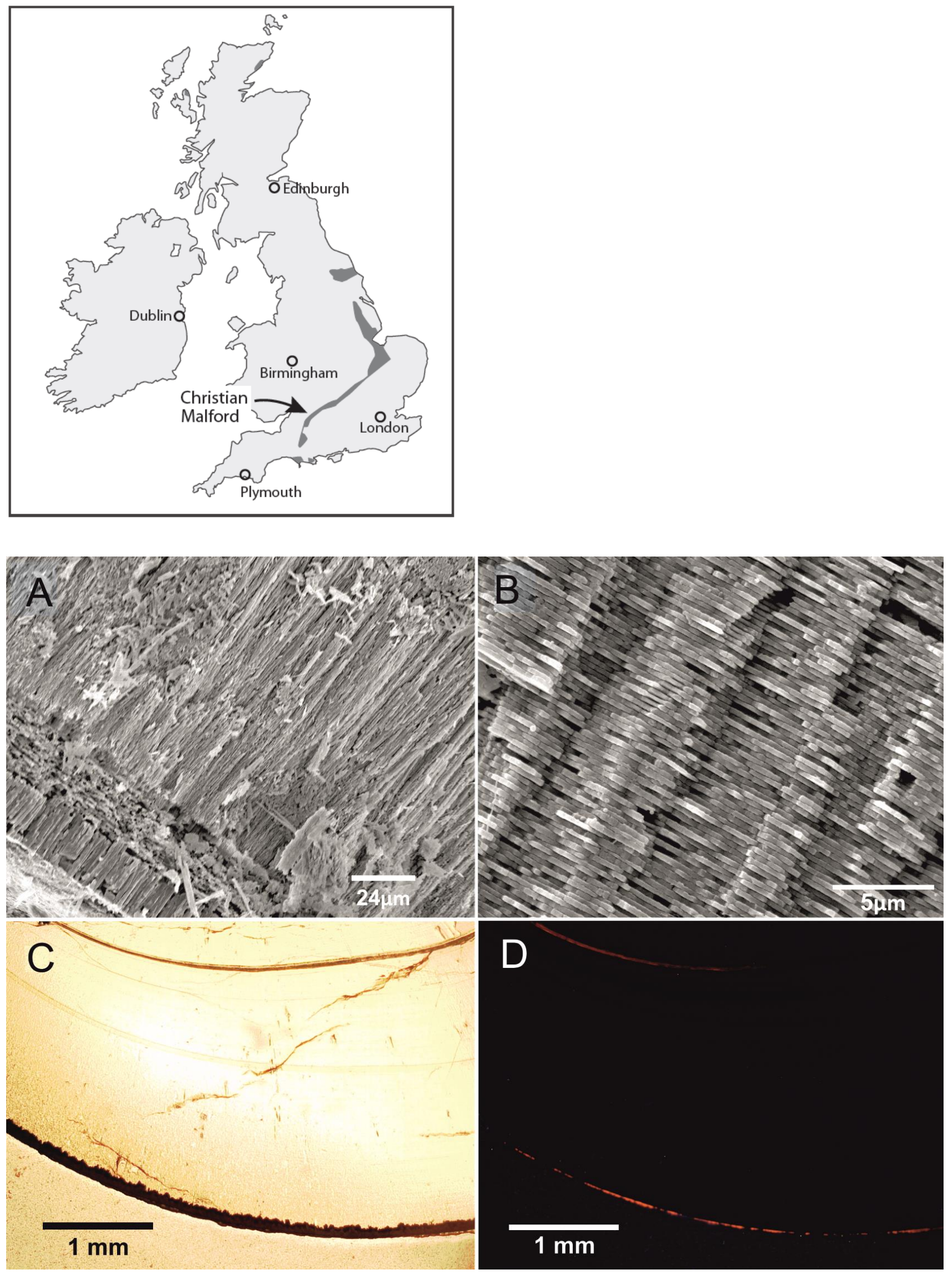


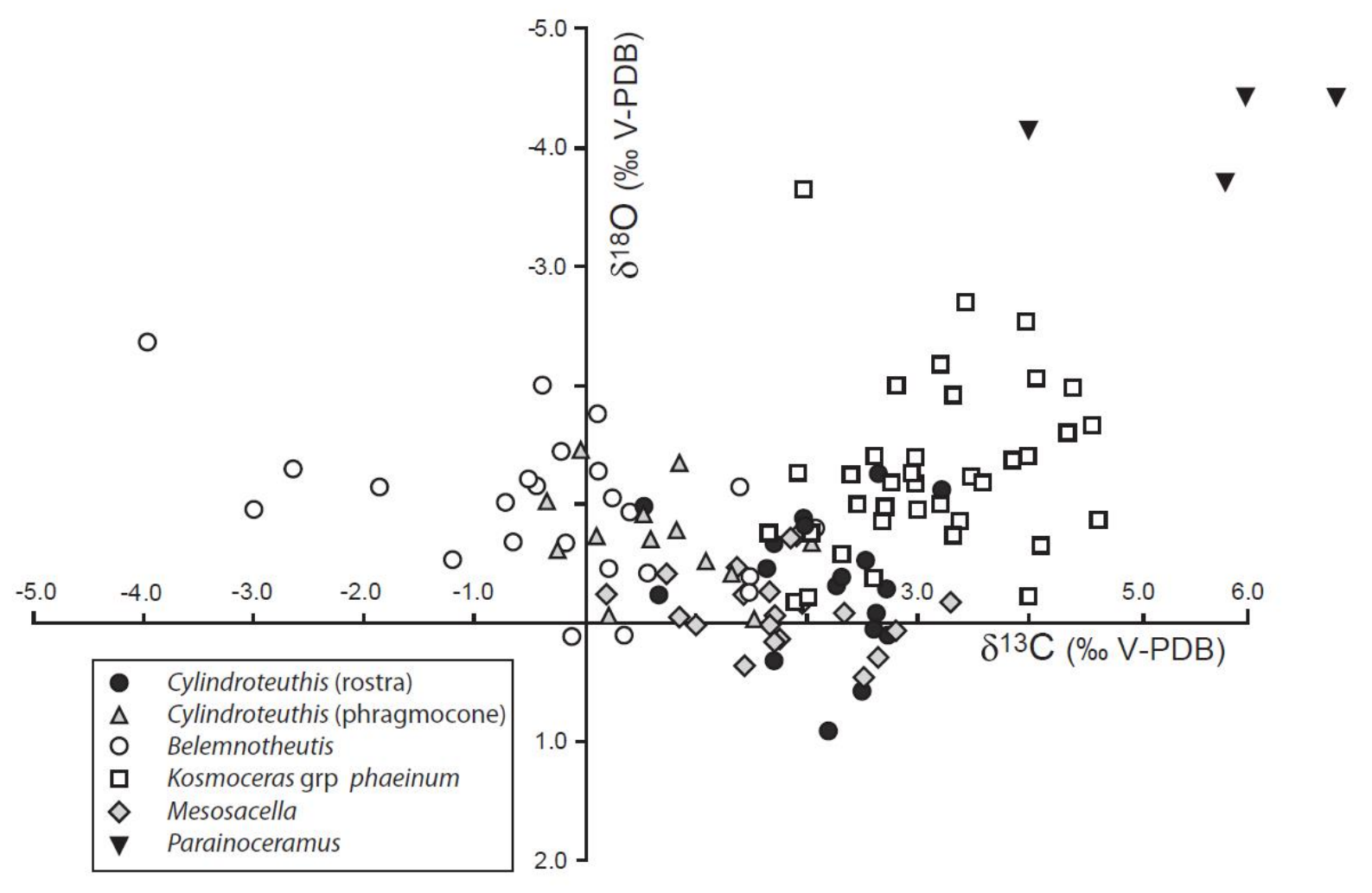



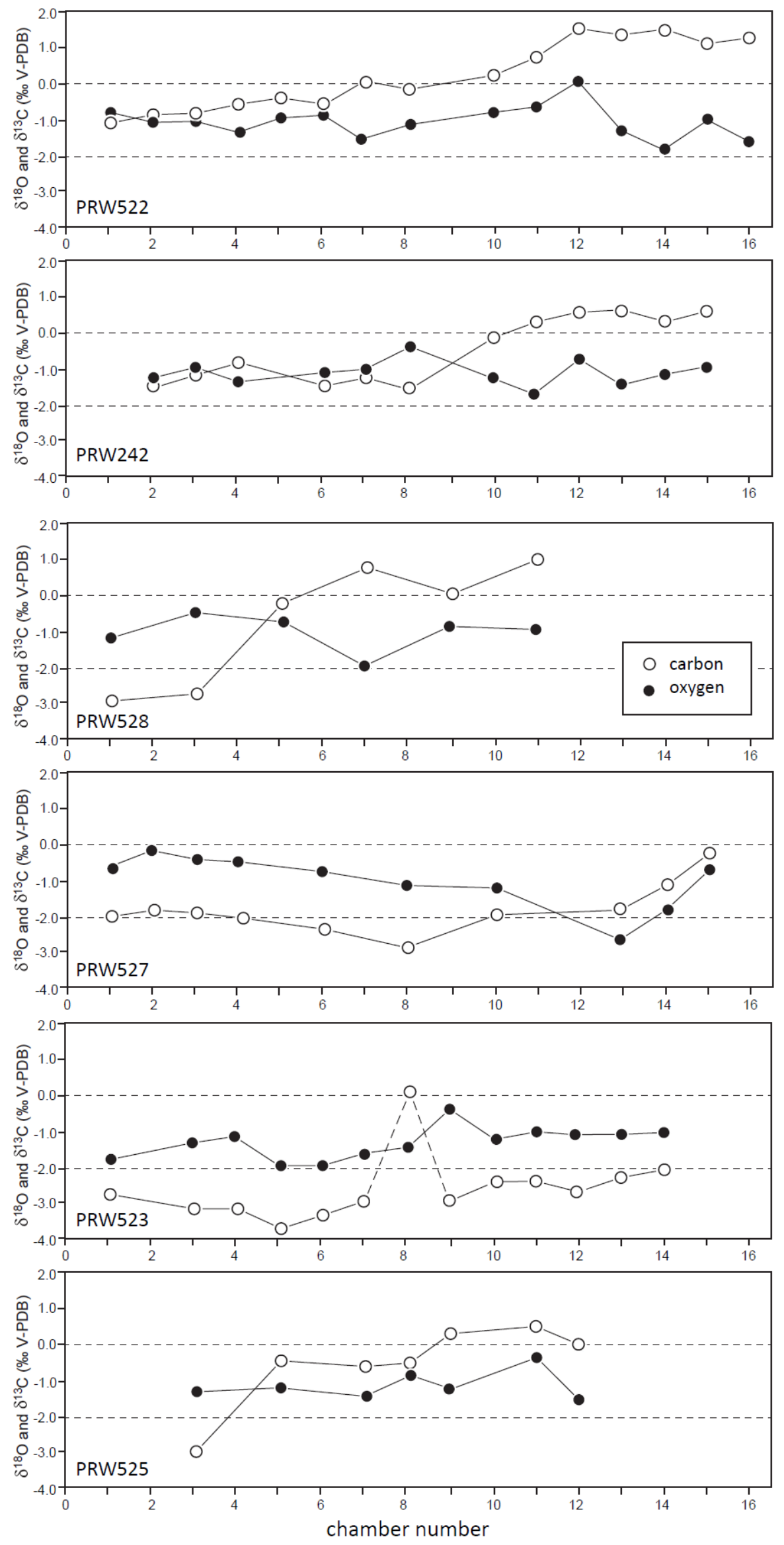

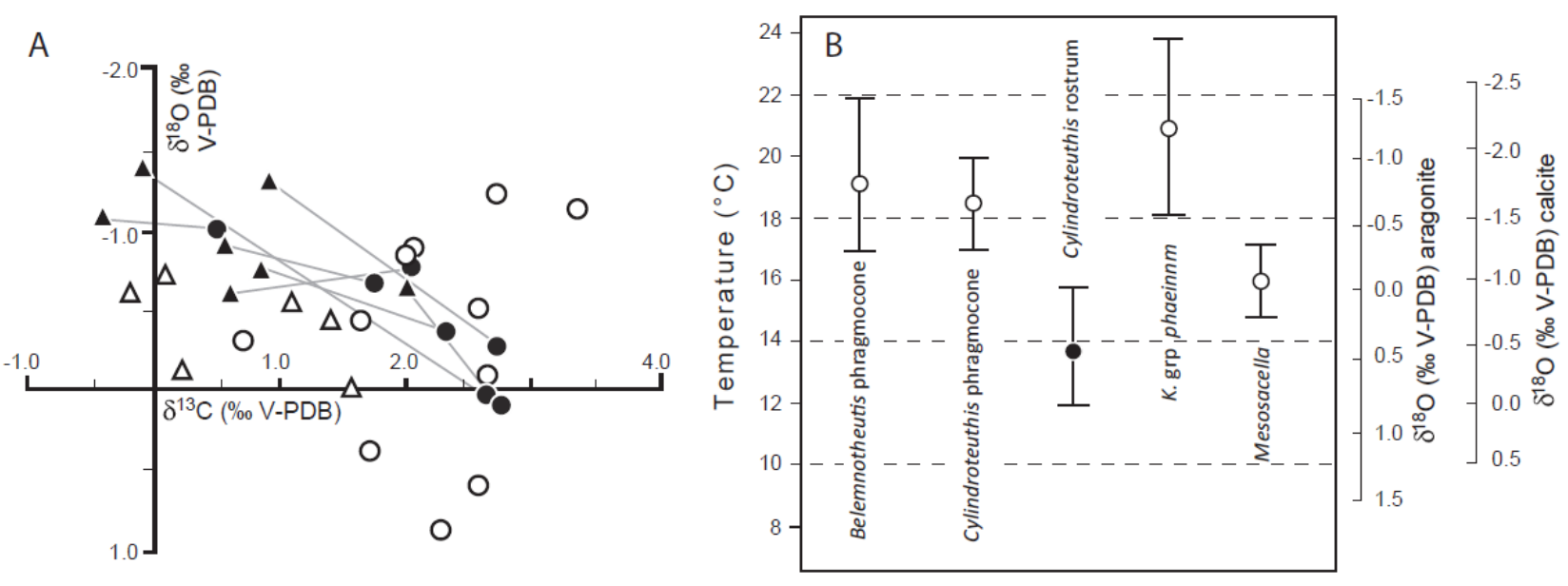